\section{Negativ etik}

Ojvind Larsen: Den samfundsetiske udfordring, Hans Reitzels Forlag, Kobenhavn, 2005, 412 sider, kr. 385,-

Den samfundsetiske udfordring er, som det skrives $i$ indledningen, motiveret af, at etikken i vore dage er blevet til 'en påtrængende levende problemstilling, som det enkelte menneske ikke kan unddrage sig' (s. 13). Det er den, fordi vi ikke har nogen overgribende og uangribelige referencer $i$ det moderne samfund, der står udenfor den samfundsmæssige diskussion. Vi står derfor til stadighed konfronteret med 'hvilke normer der skal gøres gældende i det bestemte livsforhold' (s. 17). Det er det modernes tab af religionen som horisont, der tvinger etikken frem som den måde, vi forholder os til livet og samfundet på. Det er Øjvind Larsens pointe, som han driver hjem gennem en omfattende - og til tider lidt omstændelig - diskussion af og med både filosofiens og sociologiens klassikere såvel som en række nutidige tænkere. Sociologien overtager $i$ en vis forstand religionens rolle som den forståelsesform, hvorigennem vi kan begribe og skabe en normativt funderet social orden eller sædelighed. Det er et ganske imponerende rekonstruktionsarbejde af en 'dialog' om etikkens mulighed og vilkår (noterne fylder ca. 100 sider), men faren for både læseren og forfatteren er, at fokus mistes en smule undervejs. Larsens ærinde er at argumentere for en negativ etik, da det i det moderne samfund 'ikke længere er muligt at fastsætte definitive normer om noget livsforhold' (s. 21). Det er derfor kun 'gennem kritik og negation, at der kan skabes en etisk funderet samfundsmæssig orden i det moderne samfund' (s. 22). Umuligheden af en positiv etisk teori sandsynliggøres som sagt gennem en tour de force, der tager os fra Kant, Hegel, Marx, Weber og Durkheim til Bauman, Habermas, Luhmann og utallige derimellem. Bogen har dernæst to kapitler om forholdet mellem etik og politik samt etik, ret og demokrati, hvor der drages konsekvenser af den foregående analyse først og fremmest i en læsning af Habermas, hvor Øjvind Larsen forsøger at læse ham igennem tesen om 'Das-Nein-sagen Können', dvs. det negative princip, som undertegnede ikke før har set anvendt så konsekvent på Habermas' værkkorpus.

Den samfundsetiske udfordring afsluttes med et forsvar for retsstaten og den offentlige diskussion som den negative etiks mulighedsbetingelser. Øjvind Larsen bygger her videre på problemstillinger, han har behandlet spændende og vedkommende i bl.a. Modstandens etik (1988), der er forsvaret for den frie tanke som etikkens grundlag samt Forvaltning, etik og demokrati (1996), der behandler etikkens institutionalisering i bureaukratiet. Det er dog som om, ØL denne gang har ladet genspilningen af den filosofiske og sociologiske kanon træde for stærkt frem ifht. Det egentlige ærinde. Det ændrer dog ikke ved, at man kan gå til denne bog både med interesse for 
klassisk og moderne filosofi og sociologi samt for etikkens udfordring til samfund og person.

\section{Mikkel Thorup}

\section{Rem tene, verba sequentur}

Jorgen Fafner: Retorik. Klassisk og moderne. Akademisk Forlag, Kobenhavn, 2005, 210 sider, kr. 249,-

Ovennævnte udsagn tilhører Cato, kendt som ærværdig forsvarer for den gamle republiks dyder, og dette særligt som de blev trampet under fode i triumviratets tid, hvor det var vanskeligt at vide hvem der holdt med hvem og hvad der ville holde af det sagte. Rem tene, verba sequentur (at holde sig til sagen, så følger ordene af sig selv) argumenterer for en ligefrem tale, som Cato næppe havde håbet på skulle blive indlemmet i retorikkens topologi som endnu et retorisk fif, nemlig at insistere på egen tales ikkeretoriske karakter. Res, non verba kom det til at hedde.

Grundlæggende for retorikken, er en indsigt $i$, at vi ikke alene bruger sproget til at erkende med, men også til at overbevise og til at orientere os med. Eller som Jørgen Fafner påpeger det, så udfolder menneskelivet sig ikke blot under det nødvendiges vilkår, men også under det muliges, og for det mulige må der argumenteres, eller der må i en videre forstand fremstilles. Retorik kan derfor beskrives som en filosofi for fremstillingen, for situationen, applikationen og impro- visationen.

Bogen forholder sig fra starten til den klassiske retorik, som deler erfaringerne med fremstilling op i fem rhetorices partes, fem forarbejdningsfaser, men, for et moderne perspektiv at se, også fem facetter af fremstillingens filosofi. De fem er inventio, dispositio, elocutio, memoria og actio. Omkring disse motiver er Fafner præcis og spændende.

Herefter bevæger bogen sig nærmere og nærmere en egentlig moderne retorik, og taber derved, for en idéhistorisk betragtning, en vis interesse. De følgende kapitler om 'Tekstens funktion', 'Talegenrer' og 'Tale og stil', forfølger på eksemplarisk vis bogen erklærede mål, nemlig at fremvise nogle grundbegreber for retorikken. Man bliver let og anvendeligt oplyst om hvad stilbegrebet dxkker over, hvad fx ornatus betyder. Effekten er dog, at retorikkens tekniske karakter bliver mere og mere fremtrædende som bogen skrider frem, og denne anmelder fandt at der efterhånden blev længere mellem snapsene. Dertil skal lægges, at bogen - et genoptryk fra 1977 - bliver decideret forældet når den relaterer retorikken til en bredere humanistisk videnskabsteori.

Fafner kan skrive klart og fyndigt, ingen tvivl om det. Man kan håbe, at det næste genoptryk bliver af værket Tanke og tale, der fuldt ud er helliget retorikkens historie.

Frank Beck Lassen 